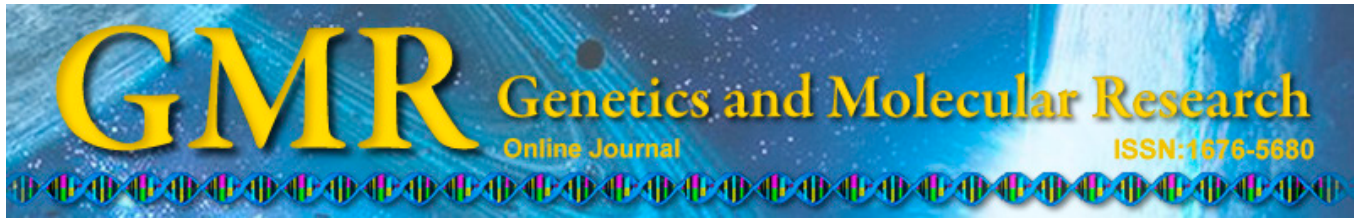

\title{
Protective effects of the antileishmanial extract of Tephrosia cinerea (L.) Pers. (Fabaceae) against cyclophosphamide-induced damage
}

\author{
A.C.S. Dias ${ }^{1}$, V.R. Moreira ${ }^{1}$, L.P. Almeida ${ }^{1}$, M.I.S. Lima ${ }^{1}$, J.L. Bezerra ${ }^{2}$, \\ M.N.S. Ribeiro ${ }^{2}$, F.R.F. Nascimento ${ }^{3}$ and S.R.F. Pereira ${ }^{1}$ \\ ${ }^{1}$ Laboratório de Genética e Biologia Molecular, Departamento de Biologia, \\ Universidade Federal do Maranhão, São Luís, MA, Brasil \\ ${ }^{2}$ Laboratório de Farmacognosia, Departamento de Farmácia, \\ Universidade Federal do Maranhão, São Luís, MA, Brasil \\ ${ }^{3}$ Laboratório de Imunofisiologia, Departamento de Patologia, \\ Universidade Federal do Maranhão, São Luís, MA, Brasil \\ Corresponding author: S.R.F. Pereira \\ E-mail: silmaregina@yahoo.com.br
}

Genet. Mol. Res. 13 (4): 9044-9055 (2014)

Received September 17, 2013

Accepted February 10, 2014

Published October 31, 2014

DOI http://dx.doi.org/10.4238/2014.October.31.19

\begin{abstract}
Tephrosia cinerea L. (Pers.) is a tropical species that exhibits antileishmanial activity in Leishmania amazonensis promastigote cultures and is commonly used to treat infections, inflammations, ulcers, nervous conditions, and diarrhea. However, no studies have investigated its effects on genetic material. Therefore, we evaluated the genotoxic potential, antigenotoxic potential, and cytotoxic effects of hydroalcoholic extracts of $T$. cinerea leaves. In an in vitro genotoxicity study, human peripheral blood leukocytes were treated for 3,24 (comet assay), or $48 \mathrm{~h}$ (cell death assay) with 22, 44, or $88 \mu \mathrm{g} / \mathrm{mL}$ plant extract. In the in vivo assay, Swiss mice were treated with 500, 1000 , or $2000 \mathrm{mg}$ extract/kg body weight by intraperitoneal injection and were evaluated $24 \mathrm{~h}$ later. Antigenotoxicity was investigated in pre- and post-treatment assays in which the animals received the plant
\end{abstract}


extract $(2000 \mathrm{mg} / \mathrm{kg}) 24 \mathrm{~h}$ before or after receiving cyclophosphamide $(50 \mathrm{mg} / \mathrm{kg})$, respectively. The extract had no genotoxic effects in the in vitro or in vivo assays. However, the extract reduced apoptotic cell death and induced necrotic cell death at concentrations that presented leishmanicidal activity in vitro. The extract also had an antigenotoxic effect, reducing the levels of genomic damage that were caused by cyclophosphamide in Swiss mice by more than $80 \%$.

Key words: Antigenotoxicity; Apoptosis; Necrosis; Tephrosia cinerea

\section{INTRODUCTION}

The genus Tephrosia (Fabaceae) contains approximately 30 species that are distributed throughout tropical and subtropical regions (Lavin, 1998). Species of this genus have a biogenetic capacity to produce structurally diverse substances, including steroids, amino acids, and flavonoids such as isoflavonoids and rotenoids (Cabizza et al., 2004). The leaves of Tephrosia cinerea (L.) Pers. are used by the general population to treat infections, inflammations, ulcers, nervous conditions, and diarrhea (Pio Corrêa, 1994).

The establishment of alternative therapies for endemic diseases involves a series of stages that extend from the initial evaluation of a compound's biological effects to the determination of toxicity and side effects and finally to clinical trials. With respect to toxicity, determining the effects of the compound on genetic material is required before a new medication can enter the market.

Leishmaniasis is an endemic disease in Brazil that is generally treated with Glucantime $^{\circledR}$ despite its known genotoxic and mutagenic activities in vivo (Lima et al., 2010). To aid the search for new leishmaniasis treatments, we extended a previous study showing that hydroalcoholic extracts of $T$. cinerea leaves exert a potent antileishmanial activity (Bezerra et al., 2006). This study aimed to evaluate the action of this plant extract on genetic material in vitro and in vivo.

\section{MATERIAL AND METHODS}

\section{Plant species}

T. cinerea leaves were collected in the Berta Langes de Morretes Garden (Ático Seabra Herbarium, Departamento de Farmácia, Universidade Federal do Maranhão) in São Luís, State of Maranhão, Brazil, in February 2007. The species was identified by Dr. Terezinha de Jesus Almeida Rêgo, and specimens were deposited and registered in the herbarium under the number 1256.

\section{Extract preparation}

Leaves were dried in a convection oven, ground, and repeatedly extracted by maceration with $70 \%$ ethanol in 72-h intervals. The solvent was replaced every $72 \mathrm{~h}$ for a total of 30 days. At the end of this process, the extracted solutions were combined, filtered, and concen- 
trated in a centrifugal evaporator under vacuum pressure at $45^{\circ}-50^{\circ} \mathrm{C}$, resulting in a $12.15 \%$ yield that was equivalent to $317.8 \mathrm{~g}$ hydroalcoholic extract. The extract was then placed in an amber bottle and refrigerated (Harbone, 1984). The desired concentrations and doses of extract were obtained by dilution in dimethylsulfoxide (DMSO).

\section{Identification of chemical compounds in plant extracts}

Phytochemical tests for phenols, flavonoids, steroids/triterpenoids, and saponins were conducted using the Liebermann-Burchard reaction, which reveals the types of secondary metabolites that are present in plant extracts. In these tests, specific reagents are added to the hydroalcoholic extract solution, and color changes and precipitate formation are measured (Matos, 1988).

\section{In vitro assays}

\section{Genotoxicity: cells and treatments}

Human leukocytes were obtained from 20-mL samples of peripheral blood collected from six healthy volunteers (three of each gender) between 20 and 30 years of age. Leukocytes were isolated using Ficoll Paque ${ }^{\mathrm{TM}}$ PLUS (GE Healthcare: Sweden; density: $0.12 \mathrm{EU} / \mathrm{mL}$ ). The pellets of mononuclear cells $(200 \mu \mathrm{L})$ were uniformly diluted in $5 \mathrm{~mL}$ complete RPMI 1640 culture medium supplemented with $0.01 \mathrm{mg} / \mathrm{mL}$ streptomycin, $0.005 \mathrm{mg} / \mathrm{mL}$ penicillin, $20 \%$ fetal bovine serum, and $2 \%$ phytohemagglutinin. The cells were treated with hydroalcoholic extract after the cultures were established.

Cell viability was determined with the trypan blue assay (10 $\mu \mathrm{L} 0.4 \%$ trypan blue per $10 \mu \mathrm{L}$ cell suspension) (Elia et al., 1993). For each treatment, 100 cells were counted, and $70 \%$ viable cells was considered the minimum acceptable viability (Ribeiro and Marques, 2003). The extract was applied at concentrations of $22,44,88,125,250$, and $500 \mu \mathrm{g} / \mathrm{mL}$ based on the antileishmanial effects of 50 and $100 \%$ extract solutions.

Cells cultured in RPMI 1640 medium without extract served as a negative control, whereas cells cultured with $10 \mu \mathrm{L}$ hydrogen peroxide $10 \mathrm{~V}(30 \mathrm{mg} / \mathrm{mL})$ for $10 \mathrm{~min}$ prior to the test were used as a positive control. The vehicle control was conducted by culturing cells with $1 \%$ DMSO. The samples were cultured for 3, 24 (comet assay), and $48 \mathrm{~h}$ (cell death assay). Slides were analyzed by fluorescent microscopy (BX51/BX52-Olympus; 516-560 nm filter, $590 \mathrm{~nm}$ amplification barrier, 400X magnification).

\section{Comet assay}

For this assay, $200 \mu \mathrm{L} 0.5 \%$ low melting point agarose was added to $20 \mu \mathrm{L}$ cell suspension. The cells were homogenized, placed on slides that were coated with $1.5 \%$ normal melting point agarose, and refrigerated. Two slides were prepared per treatment. The slides were immersed in lysis solution $(2.5 \mathrm{M} \mathrm{NaCl}, 100 \mathrm{mM} \mathrm{Na}$-EDTA, $10 \mathrm{mM}$ Tris, $\mathrm{pH} 10,10 \%$ DMSO, and $1 \%$ Triton $\mathrm{X}-100$ ) and refrigerated at $4{ }^{\circ} \mathrm{C}$ for $2 \mathrm{~h}$. The slides were then incubated for $20 \mathrm{~min}$ in $\mathrm{pH}>13$ buffer (10 M NaOH, 0.2 M EDTA, and distilled water). Electrophoresis was performed at $25 \mathrm{~V}(0.72 \mathrm{~V} / \mathrm{cm})$ and $300 \mathrm{~mA}$ for $20 \mathrm{~min}$. The slides were placed in neutralization solution (0.4 M Tris- $\mathrm{HCl}, \mathrm{pH} 7.5)$ for $15 \mathrm{~min}$ and then dried at room temperature. Finally, the slides were fixed in $100 \%$ ethanol and stained with $20 \mu \mathrm{g} / \mathrm{mL}$ ethidium bromide. 
One hundred nuclei were analyzed from each treatment group and classified according to the level of damage: class $0(<5 \%)$, class $1(5-20 \%)$, class $2(20-40 \%)$, class $3(40-94 \%)$, and class $4(>95 \%)$ (Speit and Hartmann, 1995).

The damage score was obtained by multiplying the number of nuclei in each class by the respective class value using the following equation 1 :

$$
\text { Score }=\left[\left(0 \times n_{0}\right)+\left(1 \times n_{1}\right)+\left(2 \times n_{2}\right)+\left(3 \times n_{3}\right)+\left(4 \times n_{4}\right)\right] / \text { total number of cells }
$$

\section{Cell death assay}

Cell pellets were stained with a $5-\mu \mathrm{L}$ mixture of fluorescent dyes (propidium iodide $(5 \mu \mathrm{g} / \mathrm{mL}), 15 \mu \mathrm{g} / \mathrm{mL}$ fluorescein diacetate, and $2 \mu \mathrm{g} / \mathrm{mL}$ Hoechst 3334 in phosphate-buffered saline, $\mathrm{pH} 8$, and incubated at $37^{\circ} \mathrm{C}$ for $5 \mathrm{~min}$. Three thousand cells per treatment were analyzed by fluorescence microscopy (BX51-Olympus; 40X objective) using a triple filter (DAPI, propidium, and FITC). Following Korostoff et al. (1998) and Hashimoto et al. (2003), normal, necrotic, and apoptotic cells were distinguished based on the cell staining as follows: normal cells, green cytoplasm with blue spherical nuclei; apoptotic cells, green cytoplasm with blue fragmented nuclei (apoptotic bodies); and necrotic cells, homogenous red nuclei and cytoplasm.

\section{In vivo assays}

\section{Genotoxicity: animals and treatments}

Swiss mice of reproductive age (approximately 60 days) and an average weight of 30 $\mathrm{g}$ were used for the genotoxicity assays, and 10 animals were in each treatment group. The animals were obtained from the Central Vivarium of Universidade Federal do Maranhão, Bacanga campus, São Luís, Maranhão, Brazil. The mice were housed in a conditioned environment at $22^{\circ} \pm 3^{\circ} \mathrm{C}$ and $50 \pm 20 \%$ relative air humidity with a 12-h light cycle (12 h light/12 h dark) and ad libitum access to commercial Labina Purina ${ }^{\circledR}$ chow and water. All of the procedures were completed in accordance with the Guide for the Care and Use of Laboratory Animals from the National Institutes of Health. This study was approved by the Ethics Committee in Research of the Universidade Federal do Maranhão (23115-012975/2008-43 protocol).

The doses of extract used were based on the maximum recommended limit for genotoxic studies $(2000 \mathrm{mg} / \mathrm{kg}$ ), which does not induce mortality or morbidity (Ribeiro and Marques, 2003) and considered the solubility for intraperitoneal administration. We selected doses of 2000, 1000, and $500 \mathrm{mg} / \mathrm{kg}$. Cyclophosphamide $(50 \mathrm{mg} / \mathrm{kg})$ was used as a positive control, 1\% DMSO was used as the vehicle control, and distilled water was used as the negative control. Each animal received $0.1 \mathrm{~mL} / 10 \mathrm{~g}$ of its assigned treatment by intraperitoneal injection. After 3 and $24 \mathrm{~h}$, cells were obtained from $10 \mu \mathrm{L}$ peripheral blood that was collected through a small excision at the tip of the tail and analyzed by the comet assay.

\section{Antigenotoxicity: animals and treatment}

Swiss mice (as described for the genotoxicity study) were distributed among six experimental groups: 1) pre-treatment, in which the animals received a $2000 \mathrm{mg} / \mathrm{kg}$ dose of plant 
extract followed by cyclophosphamide ( $50 \mathrm{mg} / \mathrm{kg}$ by intraperitoneal injection) $24 \mathrm{~h}$ later; 2 ) post-treatment, in which the mice received cyclophosphamide followed by the plant extract 24 $\mathrm{h}$ later; 3) plant control, in which the animals were only treated with $T$. cinerea extract (2000 $\mathrm{mg} / \mathrm{kg}$ ); 4) negative control, in which the animals were treated with sterile distilled water; 5) vehicle control, in which the mice were treated with 1\% DMSO; and 6) positive control, in which the mice only received cyclophosphamide $(50 \mathrm{mg} / \mathrm{kg})$. At the end of the study, peripheral blood cells were obtained, and the comet assay was performed as described above.

\section{Statistical analysis}

The data were analyzed using Bioestat 5.0 (Ayres et al., 2007). The in vitro results were normally distributed and therefore analyzed using parametric analysis of variance and the Tukey post-hoc test $(\mathrm{P}<0.05)$. The in vivo data did not show a normal distribution and were therefore analyzed using the non-parametric Kruskal-Wallis H-test followed by the Student-Newman-Keuls post-hoc test $(\mathrm{P}<0.05)$. The results of the cell death assay were analyzed using the chi-squared test.

\section{RESULTS}

\section{Phytochemical study}

Among the chemical substances that were present in the hydroalcoholic extract, phenol and flavonoid compounds were highly represented. In contrast, steroids/triterpenoids and saponins were present in only moderate or low amounts, respectively.

\section{Cell viability}

The cell viability was greater than $70 \%$ after both the 3- and 24-h treatments with 22 (C1), 44 (C2), and $88 \mu \mathrm{g} / \mathrm{mL}$ (C3) plant extract (Figure 1). The comet assay revealed elevated levels of dead cells with extract concentrations of 125, 250, and $500 \mu \mathrm{g} / \mathrm{mL}$ (Figure 1).

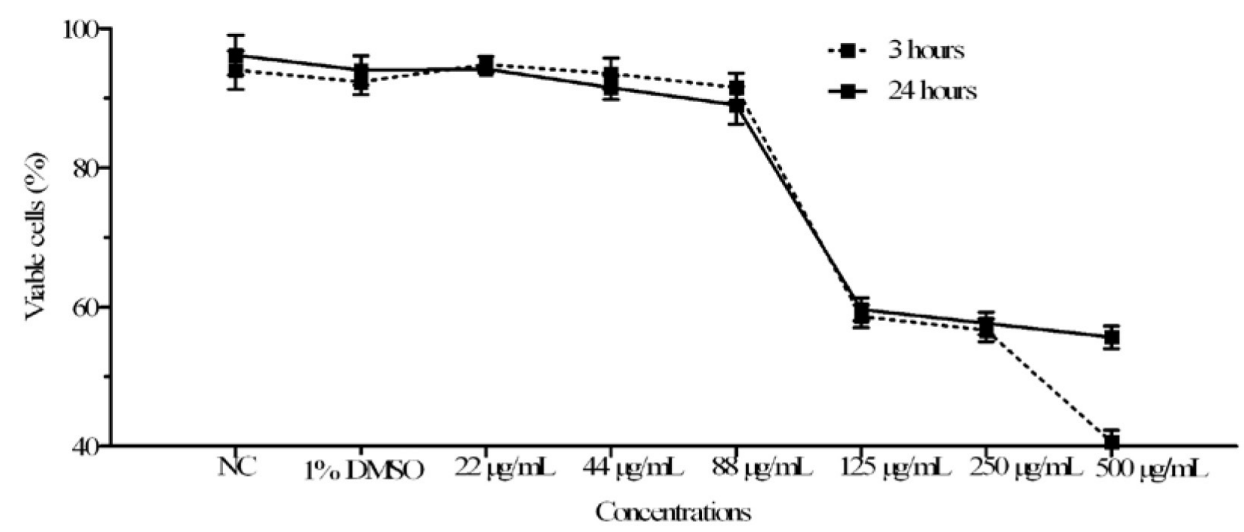

Figure 1. Viability of human leukocytes that were treated in vitro for 3 or $24 \mathrm{~h}$ with six concentrations of Tephrosia cinerea (L.) Pers. hydroalcoholic extract ( $\mathrm{NC}=$ negative control; $1 \% \mathrm{DMSO}=$ vehicle control). 


\section{In vitro comet assay}

Class 0 cells were predominant in the negative and vehicle controls (1\% DMSO) for both the 3- and 24-h treatments. A higher frequency of class 4 nuclei was observed in the positive control, indicating a high level of DNA damage. In the groups that were treated with plant extract, most cells fell into class 0 and 1, indicating that there was less DNA damage in these cells relative to the positive control. There were no statistically significant differences in damage scores between any group that was treated with the $T$. cinerea extract and the negative control (Table 1).

\begin{tabular}{|c|c|c|c|c|c|c|}
\hline \multirow[b]{2}{*}{ Group } & \multicolumn{5}{|c|}{ Class (\%) } & \multirow{2}{*}{$\begin{array}{c}\text { Scores } \\
\text { Average } \pm \text { SD }\end{array}$} \\
\hline & 0 & 1 & 2 & 3 & 4 & \\
\hline \multicolumn{7}{|l|}{$3 \mathrm{~h}$} \\
\hline $\mathrm{NC}$ & 97.7 & 2.0 & 0.3 & 0.0 & 0.0 & $0.02 \pm 0.05^{\mathrm{a}}$ \\
\hline $\mathrm{PC}$ & 1.6 & 1.6 & 0.6 & 5.6 & 90.6 & $3.94 \pm 0.17^{b}$ \\
\hline $\mathrm{VC}$ & 95.0 & 2.6 & 2.4 & 0.0 & 0.0 & $0.07 \pm 0.01^{\mathrm{a}}$ \\
\hline $\mathrm{C} 1$ & 87.0 & 10.0 & 2.7 & 0.3 & 0.0 & $0.17 \pm 0.02^{\mathrm{a}}$ \\
\hline $\mathrm{C} 2$ & 81.7 & 11.0 & 4.0 & 2.3 & 1.0 & $0.30 \pm 0.02^{\mathrm{a}}$ \\
\hline \multirow[t]{3}{*}{$\mathrm{C} 3$} & 78.1 & 13.0 & 5.3 & 2.3 & 1.3 & $0.34 \pm 0.04^{\mathrm{a}}$ \\
\hline & & & & & & $F=37.494$ \\
\hline & & & & & & $\mathrm{P}<0.0001$ \\
\hline \multicolumn{7}{|l|}{$24 \mathrm{~h}$} \\
\hline $\mathrm{NC}$ & 95.7 & 4.0 & 0.3 & 0.0 & 0.0 & $0.06 \pm 0.04^{a}$ \\
\hline $\mathrm{PC}$ & 1.3 & 0.6 & 1.0 & 7.3 & 89.8 & $3.83 \pm 0.17^{b}$ \\
\hline $\mathrm{VC}$ & 90.7 & 6.0 & 3.3 & 0.0 & 0.0 & $0.12 \pm 0.09^{\mathrm{a}}$ \\
\hline $\mathrm{C} 1$ & 90.5 & 7.6 & 1.6 & 0.3 & 0.0 & $0.12 \pm 0.05^{\mathrm{a}}$ \\
\hline $\mathrm{C} 2$ & 85.4 & 12.3 & 2.0 & 0.3 & 0.0 & $0.17 \pm 0.03^{\mathrm{a}}$ \\
\hline \multirow[t]{3}{*}{$\mathrm{C} 3$} & 81.6 & 10.6 & 3.6 & 2.6 & 1.6 & $0.32 \pm 0.09^{\mathrm{a}}$ \\
\hline & & & & & & $\mathrm{F}=56.185$ \\
\hline & & & & & & $\mathrm{P}<0.0001$ \\
\hline
\end{tabular}

$\mathrm{NC}=$ negative control (RPMI 1640 medium); $\mathrm{PC}=$ positive control (hydrogen peroxide $10 \mathrm{~V}$ ); $\mathrm{VC}=$ vehicle control ( $1 \% \mathrm{DMSO}) ; \mathrm{C} 1=22 \mu \mathrm{g} / \mathrm{mL} ; \mathrm{C} 2=44 \mu \mathrm{g} / \mathrm{mL} ; \mathrm{C} 3=88 \mu \mathrm{g} / \mathrm{mL}$. The data were analyzed using analysis of variance (one criterion) with the Tukey post-hoc test. Same letters = no significant difference. Different letters = significantly different.

\section{Cell death assay}

A highly significant difference $(\mathrm{P}<0.0001)$ in the percentages of normal, necrotic, and apoptotic cells was observed between groups, indicating that exposure to the $T$. cinerea hydroalcoholic extract alters the relative proportions of living and dying cells (Table 2). When analyzed separately and relative to the negative control, changes in the proportion of necrotic cells were highly significant for the $\mathrm{C} 1\left(\chi^{2}=61.568 ; \mathrm{P}<0.0001\right), \mathrm{C} 2\left(\chi^{2}=110.580 ; \mathrm{P}\right.$ $<0.0001)$, and $\mathrm{C} 3\left(\chi^{2}=145.300 ; \mathrm{P}<0.0001\right)$ concentrations. All of the concentrations tested induced some degree of necrotic cell death. We also observed statistically significant differences in the relative proportions of apoptotic cells $(\mathrm{P}<0.05)$ for all concentrations compared to the negative control $\left(\mathrm{C} 1: \chi^{2}=13.630\right.$ and $\mathrm{P}=0.0002 ; \mathrm{C} 2: \chi^{2}=6.586$ and $\mathrm{P}=0.01$; and $\mathrm{C} 3$ : $\chi^{2}=4.435$ and $\left.\mathrm{P}=0.0352\right)$. However, in this case, apoptotic cell death was generally reduced, not increased, by treatment with the extract. 
Table 2. Cell death induced in human leukocytes treated with Tephrosia cinerea (L.) Pers. hydroalcoholic extract for $48 \mathrm{~h}$.

\begin{tabular}{lccc}
\hline Groups & \multicolumn{3}{c}{ Cells } \\
\cline { 2 - 4 } & Normal & Necrotic & Apoptotic \\
\hline NC & 2500 & $425(14.1 \%)$ & $75(2.5 \%)$ \\
VC & 2502 & $426(14.2 \%)$ & $72(2.4 \%)$ \\
C1 & 2301 & $667(22.23 \%)^{* *}$ & $32(1.06 \%)^{*}$ \\
C2 & 2205 & $755(25.16 \%)^{* *}$ & $40(1.33 \%)^{*}$ \\
C3 & 2149 & $808(26.9 \%)^{* *}$ & $43(1.43 \%)^{*}$ \\
\hline
\end{tabular}

$\mathrm{NC}=$ negative control (RPMI 1640 medium); $\mathrm{VC}=$ vehicle control $(1 \% \mathrm{DMSO}) ; \mathrm{C} 1=22 \mu \mathrm{g} / \mathrm{mL}$ extract; $\mathrm{C} 2=44$ $\mu \mathrm{g} / \mathrm{mL}$ extract; $\mathrm{C} 3=88 \mu \mathrm{g} / \mathrm{mL}$ extract. $* * \mathrm{P}<0.0001 ; * \mathrm{P}<0.05$. The data were analyzed with the chi-squared test.

\section{In vivo comet assay}

\section{Genotoxicity}

We observed a predominance of class 0 cells for both the 3- and 24-h treatments in the negative and vehicle (1\% DMSO) control groups. Samples from the positive control group, however, exhibited a greater frequency of class 4 nuclei, indicating a high level of DNA damage. In the groups that were treated with the three concentrations of extract, most nuclei were categorized as class 0 , suggesting that there was little DNA damage. There were no statistically significant differences in damage scores between any of the groups treated with $T$. cinerea and the negative control group (Table 3).

Table 3. DNA damage scores and distribution of nuclear classes observed in an in vivo comet assay of peripheral blood leukocytes obtained from Swiss mice that were exposed to different doses of Tephrosia cinerea (L.) Pers. extract for 3 and $24 \mathrm{~h}$.

\begin{tabular}{|c|c|c|c|c|c|c|c|}
\hline \multirow[b]{2}{*}{ Group } & \multicolumn{5}{|c|}{ Class (\%) } & \multicolumn{2}{|c|}{ Scores } \\
\hline & 0 & 1 & 2 & 3 & 4 & Median & Midpoint \\
\hline \multicolumn{8}{|l|}{$3 \mathrm{~h}$} \\
\hline $\mathrm{NC}$ & 89.0 & 8.0 & 2.1 & 0.9 & 0.0 & 0.13 & $25.50^{\mathrm{a}}$ \\
\hline $\mathrm{PC}$ & 61.9 & 2.5 & 10.0 & 8.6 & 17.0 & 0.45 & $50.25^{\mathrm{b}}$ \\
\hline $\mathrm{VC}$ & 86.2 & 10.3 & 2.4 & 0.6 & 0.5 & 0.15 & $24.85^{\mathrm{a}}$ \\
\hline $\mathrm{C} 1$ & 79.3 & 13.7 & 5.6 & 1.1 & 0.3 & 0.14 & $32.40^{\mathrm{a}}$ \\
\hline $\mathrm{C} 2$ & 88.3 & 9.6 & 1.4 & 0.4 & 0.3 & 0.16 & $23.20^{\mathrm{a}}$ \\
\hline \multirow[t]{2}{*}{$\mathrm{C} 3$} & 88.1 & 9.7 & 1.7 & 0.3 & 0.2 & 0.11 & $26.80^{\mathrm{a}}$ \\
\hline & & & & & & \multicolumn{2}{|c|}{$\begin{aligned} H & =17.01 \\
P & =0.004\end{aligned}$} \\
\hline \multicolumn{8}{|l|}{$24 \mathrm{~h}$} \\
\hline $\mathrm{NC}$ & 91.7 & 5.6 & 2.0 & 0.4 & 0.3 & 0.11 & $15.90^{\mathrm{a}}$ \\
\hline $\mathrm{PC}$ & 60.0 & 1.6 & 16.6 & 5.8 & 16.0 & 0.51 & $50.95^{\mathrm{b}}$ \\
\hline $\mathrm{VC}$ & 86.4 & 9.6 & 3.2 & 0.5 & 0.3 & 0.18 & $28.25^{\mathrm{a}}$ \\
\hline $\mathrm{C} 1$ & 81.8 & 14.0 & 3.1 & 0.5 & 0.6 & 0.19 & $31.35^{\mathrm{a}}$ \\
\hline $\mathrm{C} 2$ & 85.1 & 10.6 & 2.8 & 0.6 & 0.9 & 0.20 & $27.85^{\mathrm{a}}$ \\
\hline $\mathrm{C} 3$ & 89.5 & 7.6 & 1.7 & 0.6 & 0.6 & 0.14 & $28.70^{\mathrm{a}}$ \\
\hline & & & & & & \multicolumn{2}{|c|}{$\begin{aligned} \mathrm{H} & =21.27 \\
\mathrm{P} & =0.0007\end{aligned}$} \\
\hline
\end{tabular}

$\mathrm{NC}=$ negative control (distilled water); $\mathrm{PC}=$ positive control $(50 \mathrm{mg} / \mathrm{kg}$ cyclophosphamide); $\mathrm{VC}=$ vehicle control $(1 \% \mathrm{DMSO}) ; \mathrm{C} 1=500 \mathrm{mg} / \mathrm{kg} ; \mathrm{C} 2=1000 \mathrm{mg} / \mathrm{kg} ; \mathrm{C} 3=2000 \mathrm{mg} / \mathrm{kg}$. Same letters $=$ no significant difference. Different letters = significantly different. The data were analyzed by the Kruskal-Wallis H-test test followed by the Student-Newman-Keuls post-hoc test. 


\section{Antigenotoxicity}

Table 4 presents the damage scores and distribution of nuclear classes collected for the antigenotoxicity assays. We observed a predominance of class 0 cells in samples obtained from mice in the negative control, vehicle control, and plant extract treatment groups. In contrast, a high proportion of class 4 nuclei was observed in samples from the positive control group, indicting a high level of DNA damage.

There were no differences between the damage scores of the negative control, vehicle control, and plant extract treatment groups. However, there was a significant difference $(\mathrm{P}<$ 0.05 ) between these groups and the positive control. There were also significant differences in the damage scores of the groups in which animals were treated with both cyclophosphamide and plant extract (pre- and post-treatment) and the group treated only with cyclophosphamide (positive control). The $T$. cinerea extract reduced the genomic damage caused by cyclophosphamide by 80.6 and $82.3 \%$ in the pre- and post-treatment groups, respectively. There was no significant difference in the degree of damage reduction observed with these two treatment protocols.

Table 4. Distribution of nuclear classes, DNA damage scores, and damage reduction index determined by the in vivo comet assay in peripheral blood leukocytes collected from Swiss mice treated with Tephrosia cinerea hydroalcoholic extract and cyclophosphamide with a 24 -h interval between treatments (pre-treatment and posttreatment).

\begin{tabular}{|c|c|c|c|c|c|c|c|c|}
\hline \multirow[b]{2}{*}{ Group } & \multicolumn{5}{|c|}{ Class (\%) } & \multicolumn{2}{|c|}{ Scores } & \multirow[t]{2}{*}{$\mathrm{R}(\%)$} \\
\hline & 0 & 1 & 2 & 3 & 4 & Median & Midpoint & \\
\hline $\mathrm{NC}$ & 91.7 & 5.6 & 2.0 & 0.4 & 0.3 & 0.11 & $12.75^{\mathrm{a}}$ & - \\
\hline $\mathrm{VC}$ & 86.4 & 9.6 & 3.2 & 0.5 & 0.3 & 0.14 & $20.10^{\mathrm{a}}$ & - \\
\hline $\mathrm{EC}$ & 86.0 & 9.7 & 3.9 & 0.3 & 0.1 & 0.18 & $27.65^{\mathrm{a}}$ & - \\
\hline $\mathrm{PC}$ & 65.5 & 15.6 & 3.9 & 7.1 & 7.9 & 0.73 & $55.40^{\mathrm{b}}$ & - \\
\hline Pre-treatment & 82.2 & 13.2 & 4.2 & 0.4 & 0.0 & 0.23 & $36.15^{\mathrm{a}}$ & $80.6 \%$ \\
\hline Post-treatment & 83.9 & 11.1 & 4.6 & 0.4 & 0.0 & 0.22 & $\begin{array}{c}30.95^{\mathrm{a}} \\
\mathrm{H}=35.60 \\
\mathrm{P}<0.05\end{array}$ & $82.3 \%$ \\
\hline
\end{tabular}

\section{DISCUSSION}

The use of plant species for therapeutic purposes provides a valuable screening service for drug discovery efforts. Information about the traditional manner of preparation, when analyzed from chemical and biological perspectives, can contribute to the identification of active compounds and mechanisms of action (Silva, 2006). However, these latter aims present significant challenges because plants contain numerous chemical components, and their extracts can produce biological effects that represent either the sum of the effects of each component or a synergistic effect that is greater than the sum of the parts (Serpeloni et al., 2008).

Species of the genus Tephrosia have a biogenetic capacity to produce substances of great structural diversity, including steroids, phenols, saponins, amino acids, and flavonoids such as isoflavonoids and rotenoids (Cabizza et al., 2004). In this study, we obtained results in our phytochemical analysis of $T$. cinerea extracts that were similar to those obtained in other studies of the Fabaceae family and the Tephrosia genus. Diverse groups of secondary metabolites of biological interest have been identified, including phenols, flavonoids, steroids, triterpenes, and saponins. 
The T. cinerea hydroalcoholic extract was then evaluated for cytotoxicity at concentrations that had an antileishmanial effect (Bezerra et al., 2006). We determined that the extract was not cytotoxic at concentrations that exhibit 50\% leishmanicidal activity, but it did have a cytotoxic effect at concentrations with 100\% leishmanicidal activity. Thus, higher concentrations do not represent a reasonable option for future studies.

Following the cell viability assay, the extract was analyzed for its capacity to induce genomic damage. Cells were exposed to the extract for either $3 \mathrm{~h}$, the minimum time to induce genotoxic damage, or $24 \mathrm{~h}$, the time necessary for cells to complete a cell cycle (Ribeiro and Marques, 2003), and then were subjected to the in vitro comet assay (Singh et al., 1988).

The results revealed a predominance of class 0 and 1 nuclei in the treated cells, indicating that the hydroalcoholic extract did not induce genomic damage. While this study represents the first evaluation of the genotoxic potential of extracts from the Tephrosia genus, other studies performed with plant species of the Fabaceae family and a variety of biological systems obtained similar results, i.e., an absence of genotoxicity (Macêdo et al., 2008; Zampini et al., 2008).

In this study, the $T$. cinerea hydroalcoholic extract induced cell death by necrosis at concentrations that showed antileishmanicidal activity. Necrosis is known to activate inflammatory reactions that result in the death of Leishmania (Orlofsky et al., 2002). The rupture of the plasma membrane and release of cytoplasm that occur in necrotizing cells can affect a great number of neighboring cells and even provoke further death (Grisólia et al., 2009). Thus, in addition to its direct leishmanicidal activity, the hydroalcoholic extract of $T$. cinerea also induces necrotic cell death. This combined activity maximizes the extract effect against the essentially intracellular Leishmania parasite.

In addition to inducing cell death through necrosis, the extract reduced apoptotic cell death. The absence of apoptotic induction agrees with the data showing the extract's lack of genotoxicity. The decrease in apoptosis might be explained by the presence of chemical compounds that are capable of reducing DNA damage. A number of other studies also described plant extracts that induced necrosis while inhibiting apoptotic cell death (Ikeda et al., 2003; Maruo et al., 2003; Sabir and Rocha, 2008; Vieira et al., 2010).

It must be noted that in infected individuals, apoptosis can be either useful or damaging to the host because some pathogens, including Leishmania, exploit apoptotic cell death as a survival strategy in host cells (Zamperlini et al., 2000; Hetland et al., 2004). Thus, the capacity of the $T$. cinerea extract to reduce death by apoptosis may be very important for controlling Leishmania infections.

The absence of in vitro genotoxicity in the T. cinerea hydroalcoholic extract directed the investigation to the genotoxic potential of this extract in an in vivo system because some agents are pro-mutagenic but only express this activity after biotransformation. Our in vivo results revealed that the three doses that were used did not induce DNA damage; instead, the level of DNA damage that was induced by the extract showed significant differences $(\mathrm{P}<0.05)$ compared with the positive control. Similar results were obtained by Costa et al. (2008) and Magalhães et al. (2010), who used the comet assay to study extracts of Psidium cattleianum Sabine (Myrtaceae) and Ilex paraguariensis (Aquifoliaceae), respectively.

The lack of genotoxic effects from the T. cinerea hydroalcoholic extract, both in vitro and in vivo and at concentrations that showed antileishmanial activity, is critically important for its safety for popular use. Based on these findings, we next conducted antigenotoxicity experiments using the same in vivo assays. Because there were no published 
reports about this issue, this study should be considered to be pioneering in the evaluation of $T$. cinerea antigenotoxicity.

The hydroalcoholic extract reduced the genotoxic effects induced by cyclophosphamide by 80.6 and $82.3 \%$ in the pre- and post-treatment groups, respectively. The antigenotoxic activity of the extract might be related to the presence of one or more of the metabolites identified in the extract, which included flavonoids, triterpenoids/steroids, and saponins. According to Ribeiro and Seravalli (2004), flavonoids comprise a broad class of naturally occurring substances that serve as antioxidants and block the damaging effects of free radicals (Simões et al., 2003). Neuhouser (2004) found a 40 to 58\% decrease in cancer risk among people who consumed natural products containing flavonoids, triterpenoids/steroids, phenols, alkaloids, and saponins relative to those who consumed less over follow-up periods ranging from 13 to 30 years. Therefore, flavonoids are not considered to be toxic substances (Trueba and Sanchez, 2001) but are proposed to be anticarcinogenic (Zuanazzi and Montanha, 2003).

Triterpenoids and steroids do not have genotoxic activity (Villaseñor et al., 2004), but they do exert hepatoprotective effects (Oliveira et al., 2005). Phenolic compounds and their biosynthetic precursors, which are known for their antioxidant activities, protect against damage caused by oxidative stress (Abdelwahed et al., 2006) and have antitumor activity, which is demonstrated by their capacity to inhibit cancer genesis by blocking the promotion stage through the inhibition of ornithine decarboxylase (Chang and Kinghorn, 2001). Saponins are known to be antimutagenic (Caballero-George et al., 2004; Patel et al., 2007). According to Berhow et al. (2000), a saponin extract that was obtained from soy did not mutagenize CHO cells or induce the formation of micronuclei in human lymphocytes, but it did inhibit the genotoxic activity of 2-acetoxyacetylaminofluorene.

The results obtained in this study did not indicate DNA damage in cells exposed to the $T$. cinerea extract in vivo or in vitro, and this study revealed that the metabolite-rich extract protects DNA from the genotoxic activity of cyclophosphamide.

The current treatment for leishmaniasis relies on antimony, which has known toxic effects, incomplete efficacy, and a relatively high cost. Indeed, the drug of choice that is recommended by the World Health Organization and the Brazilian Ministry of Health, Glucantime ${ }^{\mathbb{B}}$, an antimonite of $\mathrm{N}$-methylglucamine, has genotoxic and mutagenic activities in vivo (Lima et al., 2010). We showed that the antileishmanial hydroalcoholic extract of $T$. cinerea (L.) Pers. is a promising natural product for the treatment of leishmaniasis because it lacks in vitro and in vivo genotoxic effects at the concentrations that have antileishmanial activity, but it can still mitigate genomic damage, reduce apoptosis, and induce cell death by necrosis. These effects may help to reduce the parasitic load and make this extract a viable option for treating leishmaniasis. However, for this extract to be validated as a potent antileishmanial agent, further studies are necessary to determine other potential toxicological properties and the compound's mechanism of action.

\section{ACKNOWLEDGMENTS}

We thank the Conselho Nacional de Desenvolvimento Científico e Tecnológico and Fundação de Amparo à Pesquisa e Desenvolvimento Científico do Maranhão for financing this study. 


\section{REFERENCES}

Abdelwahed W, Degobert G and Fessi H (2006). Freeze-drying of nanocapsules: impact of annealing on the drying process. Int. J. Pharm. 324: 74-82.

Ayres M, Ayres Jr.M, Ayres DI and Santos AAS (2007). BioEstat 5.0: Statistical Applications in the Areas of Medical and Biological Sciences. Sociedade Civil Mamirauá, MCT-CNPq, Belém.

Berhow MA, Wagner ED, Vaughn SF and Plewa MJ (2000). Characterization and antimutagenic activity of soybean saponins. Mutat. Res. 448: 11-22.

Bezerra JL, Costa GC, Lopes TC and Carvalho ICDS (2006). Evaluation of the in vitro leishmanicidal activity of medicinal plants. Rev. Bras. Farmacogn. 16: 631-637.

Caballero-George C, Vanderheyden PM, Okamoto Y, Masaki T, et al. (2004). Evaluation of bioactive saponins and triterpenoidal aglycons for their binding properties on human endothelin ETA and angiotensin AT1 receptors. Phytother. Res. 18: 729-736.

Cabizza M, Angioni A, Melis M, Cabras M, et al. (2004). Rotenone and rotenoids in cube resins, formulations, and residues on olives. J. Agric. Food Chem. 52: 288-293.

Chang LC and Kinghorn AD (2001). Flavonoids as Cancer Chemopreventive Agents. In: Bioactive Compounds From Natural Sources (Tringali C, ed.). Taylor \& Francis, London, 577-614.

Costa TD, Vieira S, Andrade SF and Maistro EL (2008). Absence of mutagenicity effects of Psidium cattleyanum Sabine (Myrtaceae) extract on peripheral blood and bone marrow cells of mice. Genet. Mol. Res. 7: 679-686.

Elia MC, Storer RD, Harmon LS, Kraynak AR, et al. (1993). Cytotoxicity as measured by trypan blue as a potentially confounding variable in the in vitro alkaline elution/rat hepatocyte assay. Mutat. Res. 291: 193-205.

Grisólia CK, Oliveira-Filho EC, Ramos FR, Lopes MC, et al. (2009). Acute toxicity and cytotoxicity of Bacillus thuringiensis and Bacillus sphaericus strains on fish and mouse bone marrow. Ecotoxicology 18: 22-26.

Harbone JB (1984). Phytochemical Methods: A Guide to Modern Techniques of Plant Analysis. Chapman and Hall, London.

Hashimoto M, Rockenstein E, Crews L and Masliah E (2003). Role of protein aggregation in mitochondrial dysfunction and neurodegeneration in Alzheimer's and Parkinson's diseases. Neuromolecular Med. 4: 21-36.

Hetland RB, Cassee FR, Refsnes M, Schwarze PE, et al. (2004). Release of inflammatory cytokines, cell toxicity and apoptosis in epithelial lung cells after exposure to ambient air particles of different size fractions. Toxicol. In Vitro 18: 203-212.

Ikeda T, Tsumagari H, Honbu T and Nohara T (2003). Cytotoxic activity of steroidal glycosides from Solanum plants. Biol. Pharm. Bull 26: 1198-1201.

Korostoff J, Wang JF, Kieba I, Miller M, et al. (1998). Actinobacillus actinomycetemcomitans leukotoxin induces apoptosis in HL-60 cells. Infect. Immun. 66: 4474-4483.

Lavin M (1998). Origin, diversity, and biogeography of neotropical Fabaceae. Monogr. Syst. Bot. Mo. Bot. Gard. 68: 131-145.

Lima MI, Arruda VO, Alves EV, de Azevedo AP, et al. (2010). Genotoxic effects of the antileishmanial drug Glucantime. Arch. Toxicol. 84: 227-232.

Macêdo MFS, Sisenando HAAACN, Queiroz JDF, Argolo ACC, et al. (2008). Determining the genotoxicity of an aqueous infusion of Bauhinia monandra leaves. Rev. Bras. Farmacogn. 18: 509-516.

Magalhães EA, Silva Júnior GJ, Campos TA and Silva LP (2010). The evaluation of the genotoxic potency of the Pyrostegia venusta (Ker Gawl.) Miers Bignoneaceae, crude extract on bone marrow of mice. Rev. Bras. Farmacogn. 20: 65-69.

Maruo VM, Bernardi MM and Spinosa HS (2003). Toxicological evaluations of long-term consumption of Solanum lycocarpum St. Hill fruits in male and female adult rats. Phytomedicine 10: 48-52.

Matos FJA (1988). Introduction to Experimental Phytochemistry. UFC, Fortaleza.

Neuhouser ML (2004). Dietary flavonoids and cancer risk: evidence from human population studies. Nutr. Cancer 50: 1-7.

Oliveira FA, Chaves MH, Almeida FR, Lima RC, Jr., et al. (2005). Protective effect of alpha- and beta-amyrin, a triterpene mixture from Protium heptaphyllum (Aubl.) March. trunk wood resin, against acetaminophen-induced liver injury in mice. J. Ethnopharmacol. 98: 103-108.

Orlofsky A, Weiss LM, Kawachi N and Prystowsky MB (2002). Deficiency in the anti-apoptotic protein A1-a results in a diminished acute inflammatory response. J. Immunol. 168: 1840-1846.

Patel D, Shukla S and Gupta S (2007). Apigenin and cancer chemoprevention: progress, potential and promise (review). Int. J. Oncol. 30: 233-245.

Pio Corrêa P (1994). Dictionary of Useful Plants in Brazil and Cultivated Exotics. Imprensa Nacional, Ministério da Agricultura, Rio de Janeiro. 
Ribeiro LR and Marques EK (2003). The importance of Environmental Mutagenesis on Human Carcinogenesis. In: Mutagênese Ambiental (Ribeiro LR, Salvadori DMF and Marques EK, eds.). ULBRA, Canoas, 21-27.

Ribeiro EP and Seravalli EAG (2004). Chemistry of Foods. Edgard Blucher. Instituto Mauá de Tecnologia, São Paulo.

Sabir SM and Rocha JB (2008). Antioxidant and hepatoprotective activity of aqueous extract of Solanum fastigiatum (false "Jurubeba") against paracetamol-induced liver damage in mice. J. Ethnopharmacol. 120: 226-232.

Serpeloni JM, Bisarro dos RM, Rodrigues J, Campaner dos SL, et al. (2008). In vivo assessment of DNA damage and protective effects of extracts from Miconia species using the comet assay and micronucleus test. Mutagenesis 23: 501-507.

Silva AG (2006). Ethnopharmacological evaluation of plants that are popularly used by communities of Camboriú and Ibirama in Santa Catarina. Rev. Univ. C. Farm. 11: 112-120.

Simões CMO, Schenkel EP, Gosmann G and Mello JP (2003). Flavonoid Pharmacognosy of the Plant to Medicine. UFRGS/UFSC, Porto Alegre, 577-614.

Singh NP, McCoy MT, Tice RR and Schneider EL (1988). A simple technique for quantitation of low levels of DNA damage in individual cells. Exp. Cell Res. 175: 184-191.

Speit G and Hartmann A (1995). The contribution of excision repair to the DNA effects seen in the alkaline single cell gel test (comet assay). Mutagenesis 10: 555-559.

Trueba GP and Sanchez GM (2001). Flavonoids as natural antioxidants. Acta Farm. Bonaerense 20: 297-306.

Vieira PM, Costa PM, Ribeiro e Silva and Chen-Chen L (2010). Assessment of the genotoxic, antigenotoxic, and cytotoxic activities of the ethanolic fruit extract of Solanum lycocarpum A. St. Hill. (Solanaceae) by micronucleus test in mice. J. Med. Food 13: 1409-1414.

Villaseñor IM, Canlas AP, Faustino KM and Plana KG (2004). Evaluation of the bioactivity of triterpene mixture isolated from Carmona retusa (Vahl.) Masam leaves. J. Ethnopharmacol. 92: 53-56.

Zamperlini GC, Santiago-Silva M and Vilegas W (2000). Solid-phase extraction of sugar cane soot extract for analysis by gas chromatography with flame ionisation and mass spectrometric detection. J. Chromatogr. A 889: 281-286.

Zampini IC, Villarini M, Moretti M, Dominici L, et al. (2008). Evaluation of genotoxic and antigenotoxic effects of hydroalcoholic extracts of Zuccagnia punctata Cav. J. Ethnopharmacol. 115: 330-335.

Zuanazzi JAS and Montanha JA (2003). Pharmacognosy of Phenolic Compounds From Plants to Medicine. UFRGS/ UFSC, Porto Alegre, 519-536. 